\title{
Pirimiphos-Methyl Resistance Status of Field Populations of Culex pipiens (Diptera: Culicidae) From Grand Tunis Area, Northeast Tunisia
}

Ahmed Tabbabi ${ }^{{ }^{*}}$, Jaber Daaboub ${ }^{1,2}$, Ali Laamari ${ }^{1}$, Raja Ben Cheikh ${ }^{1}$ and Hassen Ben Cheikh ${ }^{1}$

${ }^{1}$ Laboratory of Genetics, Faculty of Medicine of Monastir, Monastir University, 5019, Monastir, Tunisia

${ }^{2}$ Department of Hygiene and Environmental Protection, Ministry of Public Health, 1006, Bab Saadoun, Tunis, Tunisia

\begin{abstract}
Mosquito species are responsible for the transmission of many parasitic diseases and their control leads to the phenomenon of resistance to insecticides. Five Culex pipiens samples were collected from various localities of Grand Tunis area, Northeast Tunisia, between June 2003 and November 2005. All the studied samples were resistant to pirimiphos methyl (organophosphorus insecticide). Our results showed the implication of insensitive acetylcholinesterase and overproduced esterases in the résistance of the Tunisian populations of Culex pipiens. Results were discussed in relation to resistance mechanism.
\end{abstract}

Keywords: Culex pipiens; Resistance; Pirimiphos-methyl; Insensitive acetylcholinesterase; Overproduced esterases; Northeast Tunisia

\section{Introduction}

In addition to their nuisance, mosquitoes cause vector-borne diseases [1-3] and their impact on human health is very considerable [4]. Worldwide, mosquito species such as Culex are responsible for the transmission of parasitic diseases such as filariasis, yellow fever and West Nile virus $[5,6]$. Mosquito control by insecticides is very effective on culicidae mosquitoes, but has several disadvantages. In addition to a detrimental effect on aquatic life, they can be the cause of various environmental problems [5], in particular the phenomenon of insect resistance to insecticides [7-12].

Due to the problem of resistance of vectors to chemical insecticides, several alternative insecticides have been developed to evaluate their efficiencies. Pirimiphos-methyl is an organophosphorus (OP) insecticide having a fast action with less toxicity for humans and environment. The use of this insecticide against mosquito adults has already been reported [13-15]. The low remanence of pyrimiphosmethyl, used as adulticide, is due to its high vapor pressure which diffuses it rapidly into the ambient atmosphere $[16,17]$. It should be mentioned that according to our knowledge, no published studies have been done on resistance of Culex pipiens to pirimiphos methyl in Tunisia.

The aim of this study was to determine the pirimiphos-methyl resistance status of field populations of Culex pipiens (Diptera: Culicidae) from Grand Tunis Area, Northeast Tunisia.

\section{Materials and Methods}

\section{Study area}

Grand Tunis is the name for the greatest metropolitan area in Tunisia, which assembles four of the following states: Tunis, Ariana, Manouba and Ben Arous.

\section{Mosquitoes}

Five Culex pipiens samples were collected at preimaginal stages from breeding sites in 5 localities between June 2003 and November 2005 (Table 1 and Figure 1). Reference strains included S-Lab, an insecticide-susceptible strain without any known resistance genes [18]. SA2 and SA5 were used as references of resistant strains with A2-B2 and A5B5, respectively.

\section{Bioassays}

Assays were performed as described by Raymond et al. [19], using ethanol solutions of pirimiphos methyl (99\% [AI]), brought from laboratory Dr Ehrenstorfer, Germany, and propoxur (99.9\% [AI], Bayer AG, Leverkusen, Germany). The effect on OPs resistance of 2 synergists, the DEF (98\% [AI], Chem Service, England), and the $\mathrm{Pb}$ (94\% [AI], Laboratory Dr Ehrenstorfer, Germany), was studied.

\section{Over-produced esterases}

Esterases were characterized on homogenates of adult thorax and abdomen according to the method of Pasteur et al. [20,21].

\section{Data analysis}

Data were subjected to probit analysis [22] using a BASIC program [19].

\section{Results and Discussion}

The linearity of the dose-mortality response was rejected for all samples, with the exception of S-Lab and 3 field samples (\#2, 3, and 5). All the studied samples, collected between June 2003 and November

\begin{tabular}{|c|c|c|c|c|c|}
\hline Code & Locality & $\begin{array}{c}\text { Breeding } \\
\text { sites }\end{array}$ & $\begin{array}{c}\text { Date of } \\
\text { collection }\end{array}$ & $\begin{array}{r}\text { Mosquito } \\
\text { control (used } \\
\text { insecticides) }\end{array}$ & $\begin{array}{c}\text { Agricultural } \\
\text { pest control }\end{array}$ \\
\hline 1 & Sidi Thabet & Ditch & Aug, 2004 & Rare (C, P) & Yes \\
\hline 2 & Sokra & Canal & June, 2003 & $\begin{array}{c}\text { Very frequent (C, } \\
\text { Pm, tF, P, D) }\end{array}$ & Yes \\
\hline 3 & Mannouba & River & June, 2005 & Occasional (P, D) & Yes \\
\hline 4 & Ouardia & Ditch & Aug, 2005 & $\begin{array}{r}\text { Very frequent (C, } \\
\text { F, P, D) }\end{array}$ & None \\
\hline 5 & Ezzahra & Ditch & Nov, 2005 & $\begin{array}{r}\text { Very frequent (C, } \\
\text { F, P, D, T) }\end{array}$ & None \\
\hline C: Chlorpyrifos; T: Temephos; Pm: Pirimiphos methyl; F: Fenitrithion; P:
\end{tabular}
Permethrin; D: Deltamethrin

Table 1: Geographic origin of Tunisian populations, breeding site characteristics and insecticide control.

*Corresponding author: Tabbabi A, Laboratory of Genetics, Faculty of Medicine of Monastir, Monastir University, 5019, Monastir, Tunisia, Tel: 0021697085424; Fax: 73460737; E-mail: tabbabiahmed@gmail.com

Received April 17, 2017; Accepted April 28, 2017; Published May 05, 2017

Citation: Tabbabi A, Daaboub J, Laamari A, Ben Cheikh R, Ben Cheikh H (2017) Pirimiphos-Methyl Resistance Status of Field Populations of Culex pipiens (Diptera: Culicidae) From Grand Tunis Area, Northeast Tunisia. Hereditary Genet 6: 175 doi:10.4172/2161-1041.1000175

Copyright: ( 2016 Tabbabi A, et al. This is an open-access article distributed under the terms of the Creative Commons Attribution License, which permits unrestricted use, distribution, and reproduction in any medium, provided the original author and source are credited. 


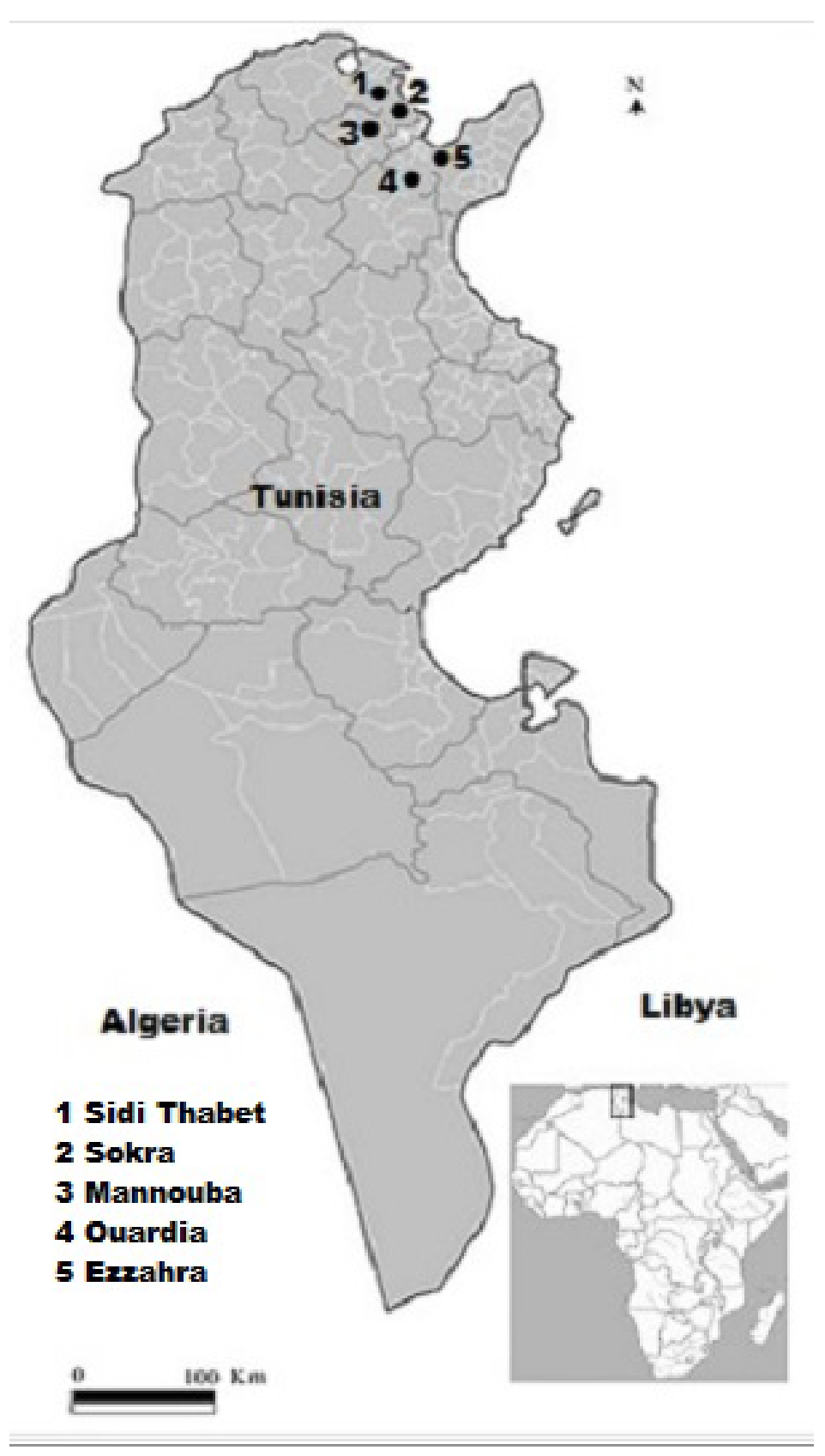

Figure 1: Geographic origin of Tunisian populations.

2005, were resistant to pirimiphos methyl. The RR50 ranged from 12.6 in sample \#3 to 231 in sample \#5 (Table 2). This can be explained by the massive use of this insecticide in the control against these insects but the survey carried out is not in agreement with the results found: only one locality by five prospected was the object of control by pirimiphosmethyl.

The DEF decreased significantly the tolerance to pirimiphos methyl in S-Lab and the five field samples (SR50>1, p<0.05) (Table 2). The DEF had a synergistic effect significantly higher than that recorded in S-Lab (RSR $>1$ ) only in samples \#4. Therefore, the increased detoxification by EST (and/or GST) was involved in the pirimiphos methyl resistance only in this sample. This mechanism accounts for only a part of this resistance because the RR50 remained significant in the presence of the DEF (RR50>1, $\mathrm{p}<0.05)$. The addition of $\mathrm{Pb}$ decreased significantly the tolerance to pirimiphos-methyl in S-Lab $(S R 50=7.24, \mathrm{p}<0.05)$ and in samples \#2 and \#5, but the SR was significantly higher than that recorded in S-Lab only in sample \#5 (Table 2). Therefore, the increased detoxification by the CYP450 was involved in the pirimiphos methyl resistance only in this population. This mechanism explains only a part of this resistance because RR50 remained significant in the presence of $\mathrm{Pb}(\mathrm{RR} 50>1, \mathrm{p}<0.05)$. Our synergist study showed that the increased detoxification by EST (and/or GST) and CYP450 had only a minor role in the pirimiphos methyl resistance, results already confirmed by previous studies $[23,24]$. It should be noted that esterases, GSTs and cytochrome $\mathrm{P} 450$ enzymes are not always sensitive to used synergists. 


\begin{tabular}{|c|c|c|c|c|c|c|c|c|c|c|c|c|c|}
\hline \multirow[b]{2}{*}{ Population } & \multicolumn{3}{|c|}{ Pirimiphosmethyl } & \multicolumn{5}{|c|}{ Pirimiphosmethyl +DEF } & \multicolumn{5}{|c|}{ Pirimiphosmethyl $+\mathrm{Pb}$} \\
\hline & $\begin{array}{c}\mathrm{LC}_{50} \text { in } \\
\mu \mathrm{g} / \mathrm{l} \\
\text { (a) }\end{array}$ & $\begin{array}{l}\text { Slope } \\
\pm \text { SE }\end{array}$ & $\begin{array}{l}\mathrm{RR}_{50} \\
\text { (a) }\end{array}$ & $\begin{array}{l}\mathrm{LC}_{50} \text { in } \mu \mathrm{g} / \mathrm{l} \\
\text { (a) }\end{array}$ & $\begin{array}{l}\text { Slope } \\
\pm \text { SE }\end{array}$ & $\begin{array}{l}\mathrm{RR}_{50} \\
\text { (a) }\end{array}$ & $\begin{array}{l}\mathrm{SR}_{50} \\
(\mathrm{a})\end{array}$ & RSR & $\begin{array}{c}\mathrm{LC}_{50} \text { in } \\
\mu \mathrm{g} / \mathrm{I} \\
\text { (a) }\end{array}$ & $\begin{array}{l}\text { Slope } \\
\pm \text { SE }\end{array}$ & $\begin{array}{l}\mathrm{RR}_{50} \\
\text { (a) }\end{array}$ & $\begin{array}{l}\mathrm{SR}_{50} \\
(\mathrm{a})\end{array}$ & RSR \\
\hline Slab & $\begin{array}{c}2.9 \\
(2.5-3.4)\end{array}$ & $\begin{array}{c}2.34 \\
\pm 0.18\end{array}$ & - & $\begin{array}{c}0.30 \\
(0.16-0.56)\end{array}$ & $\begin{array}{c}1.7 \\
\pm 0.42\end{array}$ & - & $\begin{array}{c}9.79 \\
(6.16-15.5)\end{array}$ & - & $\begin{array}{c}0.40 \\
(0.31- \\
0.55)\end{array}$ & $\begin{array}{c}1.47 \\
\pm 0.18\end{array}$ & - & $\begin{array}{c}7.2 \\
(5.7-9.1)\end{array}$ & - \\
\hline 1-Sidi Thabet & $\begin{array}{c}67 \\
(29-155)\end{array}$ & $\begin{array}{c}1.16 \\
\pm 0.25\end{array}$ & $\begin{array}{c}23.2 \\
(15.2-35.5)\end{array}$ & $\begin{array}{c}24 \\
(16-35)\end{array}$ & $\begin{array}{c}2.15 \\
\pm 0.32\end{array}$ & $\begin{array}{c}82.2 \\
(49.5-136)\end{array}$ & $\begin{array}{c}2.77 \\
(1.72-4.45)\end{array}$ & 0.28 & $\begin{array}{c}43 \\
(37-49)\end{array}$ & $\begin{array}{c}2.34 \\
\pm 0.21\end{array}$ & $\begin{array}{c}107 \\
(85.5-133)\end{array}$ & $\begin{array}{c}1.5 \\
(1.04-2.3)\end{array}$ & 0.22 \\
\hline 2-Sokra & $\begin{array}{c}135 \\
(102-184)\end{array}$ & $\begin{array}{c}1.17 \\
\pm 0.12\end{array}$ & $\begin{array}{c}46.2 \\
(37.4-57.1)\end{array}$ & $\begin{array}{c}60 \\
(32-110)\end{array}$ & $\begin{array}{l}5.37^{* *} \\
\pm 3.46\end{array}$ & $\begin{array}{c}201 \\
(59.1-688)\end{array}$ & $\begin{array}{c}2.24 \\
(0.63-7.96)\end{array}$ & 0.22 & $\begin{array}{c}37 \\
(19-72)\end{array}$ & $\begin{array}{c}2.52 \\
\pm 0.64\end{array}$ & $\begin{array}{c}94.1 \\
(61.2-144)\end{array}$ & $\begin{array}{c}3.5 \\
(2.1-5.7)\end{array}$ & 0.49 \\
\hline 3-Mannouba & $\begin{array}{c}37 \\
(31-43)\end{array}$ & $\begin{array}{c}1.57 \\
\pm 0.13\end{array}$ & $\begin{array}{c}12.6 \\
(10.4-15.3)\end{array}$ & $\begin{array}{c}6.9 \\
(4.7-10)\end{array}$ & $\begin{array}{l}1.21^{*} \\
\pm 0.16\end{array}$ & $\begin{array}{c}16.7 \\
(12.1-23.0)\end{array}$ & $\begin{array}{c}5.33 \\
(4.22-6.72)\end{array}$ & 0.75 & $\begin{array}{c}32 \\
(15-66)\end{array}$ & $\begin{array}{c}2.2 \\
\pm 0.7\end{array}$ & $\begin{array}{c}80.3 \\
(43.1-149)\end{array}$ & $\begin{array}{c}1.1 \\
(0.62-2.0)\end{array}$ & 0.16 \\
\hline 4-Ouardia & $\begin{array}{c}38 \\
(27-52)\end{array}$ & $\begin{array}{c}2.52 \\
\pm 0.43\end{array}$ & $\begin{array}{c}13.1 \\
(9.02-19.0)\end{array}$ & $\begin{array}{c}1.3 \\
(0.33-2.9)\end{array}$ & $\begin{array}{c}0.34 \\
\pm 0.08\end{array}$ & $\begin{array}{c}4.5 \\
(2.8-7.0)\end{array}$ & $\begin{array}{c}28.5 \\
(20.0-40.6)\end{array}$ & 2.9 & $\begin{array}{c}23 \\
(15-41)\end{array}$ & $\begin{array}{l}1.07^{*} \\
\pm 0.15\end{array}$ & $\begin{array}{c}58.5 \\
(44.4-77.2)\end{array}$ & $\begin{array}{c}1.6 \\
(1.09-2.4)\end{array}$ & 0.22 \\
\hline 5-Ezzahra & $\begin{array}{c}676 \\
(656-689)\end{array}$ & $\begin{array}{c}19.2 \\
\pm 2.36\end{array}$ & $\begin{array}{c}231 \\
(172-311)\end{array}$ & $\begin{array}{c}376 \\
(258-789)\end{array}$ & $\begin{array}{l}1.33^{*} \\
\pm 0.32\end{array}$ & $\begin{array}{c}1262 \\
(726-2195)\end{array}$ & $\begin{array}{c}1.79 \\
(1.24-2.59)\end{array}$ & 0.18 & $\begin{array}{c}27 \\
(18-38)\end{array}$ & $\begin{array}{c}2.8 \\
\pm 0.71\end{array}$ & $\begin{array}{c}67.6 \\
(44.2-103)\end{array}$ & $\begin{array}{c}24.8 \\
(15.6-39.3)\end{array}$ & 3.4 \\
\hline
\end{tabular}

(a) $95 \% \mathrm{Cl}$; ${ }^{*}$ The log dose-probit mortality response is parallel to that of S-Lab; ** Parallelism test positif but without probability.

RR50, resistance ratio at LC50 (RR50=LC50 of the population considered / LC50 of Slab); SR50, synergism ratio (LC50 observed in absence of synergist / LC50 observed in presence of synergist). RR and SR considered significant $(P<0.05)$ if their $95 \% \mathrm{Cl}$ did not include the value 1.

$R S R$, relative synergism ratio ( $R R$ for insecticide alone / $R R$ for insecticide plus synergist).

Table 2: Pirimiphosmethyl resistance characteristics of Tunisian Culex pipiens in presence and absence of synergists $\mathrm{DEF}$ and $\mathrm{Pb}$.

Mortality caused by propoxur were $0 \%$ in sample \#5 which showed the highest resistance levels to studied pirimiphos-methyl insecticide, $18 \%$ in sample \#4, $21 \%$ in sample \#2, $46 \%$ in sample \# 1 and $48 \%$ in sample \#3. The mortality due to propoxur was significantly correlated with the LC50 of pirimiphos methyl $(\mathrm{P}<0.05)$ indicates an acetylcholinesterase insensitive. Five esterases were observed in studied field samples. The esterase $\mathrm{C} 1$ encoded by the Est-1 locus and four esterases encoded by the Ester super locus: A1, A2-B2, A4-B4 (and/or A5-B5, which has the same electrophoretic mobility) and B12. One or several esterases were detected in all the studied samples. The A1 esterases were observed only in samples \#3 and \#5, with a low phenotypic frequency of 0.03 . The C1 esterases were observed only in samples \#1 and \#5, with a low phenotypic frequency of 0.06 and 0.11 , respectively. The other esetrases were detected almost in all collected samples with frequency which vaired between 0.03 and 0.48 . Esterases play an important role in the resistance of several insects in the world [25-31]. Our results confirms the previous results of Ben Cheikh et al. [28] which reported the existence of a correlation between the frequency of individuals possessing the Ace-1R allele and those overproduced esterases A and B among the Tunisian populations of Culex pipiens. However, other studies are not in agreement with these results and suggested that overproduction of esterases and modifications of AChE are not correlated [11,12].

\section{Acknowledgements}

This work was kindly supported by the Ministry of Higher Education and Scientific Research of Tunisia by funds allocated to the Research Unit (Génétique 02/UR/08-03) and by DHMPE of the Minister of Public Health of Tunisia. We are very grateful to $S$. Ouanes, for technical assistance, A. Ben Haj Ayed and I. Mkada for help in bioassays, S. Saïdi, Tunisian hygienist technicians for help in mosquito collecting, and M. Nedhif and M. Rebhi for their kind interest and help.

\section{References}

1. Seye F, Ndione RD, Ndiaye M (2006) Effets larvicides des produits de neem (huile de neem pure et neemix) compares a deux insecticides chimiques de synthese (la deltamethrine et le fenitrothion) sur les larves du moustique culex quinquefasciatus (diptera: culicidae), J Sci Tech 4: 27-36.

2. Youssef L, Driss B, Youssef E, Omar L, Khadija E, et al. (2011) Cartographie de la faune culicidienne dans la province de Khémisset (Maroc). Sci Lib Edi Mersenne 3: 7

3. Wasfi F, Dachraoui K, Cherni S, Bosworth A, Barhoumi W, et al. (2016) West Nile virus in Tunisia, 2014 : First isolation from mosquitoes. Acta Trop 159: 106-110.
4. Pascal D, Pierre M, Pierre F (2001) Les moustiques d'intérêt médical. Revue Française des Laboratoires 338: 27-36.

5. Aouinty B, Oufara S, Mellouki F, Mahari S (2006) Évaluation préliminaire de l'activité larvicide des extraits aqueux des feuilles du ricin (Ricinus communis L.) et du bois de thuya (Tetraclinis articulata (Vahl) Mast.) sur les larves de quatre moustiques culicidés: Culex pipiens (Linné), Aedes caspius (Pallas) Culiseta longiareolata (Aitken) et Anopheles maculipennis (Meigen). Biotechnol Agron Soc Environ 10: 67-71.

6. Krida G, Diancourt L, Bouattour A, Rhim A, Chermiti B, et al. (2011) Assessment of the risk of introduction to Tunisia of the Rift Valley fever virus by the mosquito Culex pipiens. Bull Soc Pathol Exot 104: 250-259.

7. Cui F, Tan Y, Qiao CL (2007) Filariasis vector in China: Insecticide resistance and population structure of mosquito Culex pipiens complex. Pest Manag Sci 63: 453-458.

8. Daaboub J, Ben Cheikh R, Lamari A, Ben Jha I, Feriani M, et al. (2008) Resistance to pyrethroid insecticides in Culex pipiens pipiens (Diptera: Culicidae) from Tunisia. Acta Tropica 107: 30-36.

9. Kioulos I, Kampouraki A, Morou E, Skavdis G, Vontas J (2013) Insecticide resistance status in the major West Nile virus vector Culex pipiens from Greece. Pest Manag Sci 70: 623-627.

10. El-Ouali Lalami A, El-Akhal F, El-Amri N, Maniar S, Faraj C (2014) Etat de la résistance du moustique Culex pipiens vis-à-vis du téméphos au centre du Maroc. Bull Soc Pathol Exot 107: 194-198.

11. Tabbabi A, Daaboub J, Laamari A, Ben Cheikh H (2016) New Esterases Amplification Involved in Organophosphate Resistance in Culex Pipiens Mosquitoes from Tunisia. The Journal of Middle East and North Africa Sciences 2: $1-2$

12. Tabbabi A, Laamari A, Daaboub J, Ben-Jha I, Ben-Cheikh H (2017) Crossresistance to pyrethroid and organophosphorus insecticides induced by selection with temephos in the potential mosquito vector of west Nile Virus (Culex pipiens) from Tunisia. The Journal of Middle East and North Africa Sciences 3: 25-29.

13. Das M, Srivastava BN, Rao CK, Thapar BR, Sharma GK (1987) Field trial of the effectiveness of indoor-spraying with pirimiphos-methyl emulsion for malaria control in a tribal area of Phulbani district, Orissa State, India. Med Vet Entomol 1: 289-295.

14. Nasir SM, Ahmad N, Shah MA, Azam CM (1982) A large-scale evaluation of pirimiphos-methyl 25\% WP during 1980-1981 for malaria control in Pakistan. J Trop Med Hyg 85: 239-244.

15. Chang MS, Ho BC, Chan KL (1991) Efficacy of diethylcarbamazine and pirimiphos-methyl residual spraying in controlling brugian filariasis. Trop Med Parasitol 42: 95-102.

16. Kolaczinsky JH, Fanello C, Hervé JP, Conway DJ, Carnevale P, et al. (2000) Experimental and molecular genetic analysis of the impact of pyrethroid and 
Citation: Tabbabi A, Daaboub J, Laamari A, Ben Cheikh R, Ben Cheikh H (2017) Pirimiphos-Methyl Resistance Status of Field Populations of Culex pipiens (Diptera: Culicidae) From Grand Tunis Area, Northeast Tunisia. Hereditary Genet 6: 175. doi:10.4172/2161-1041.1000175

nonpyrethroid insecticide impregnated bednets for mosquito control in an area of pyrethroid resistance. Bull Entomol Res 90: 125-132.

17. Miller JE, Lindsay SW, Armstrong JRM (1991) Experimental hut trials of bednets impregnated with synthetic pyrethroid or organophosphate insecticide for mosquito control in the Gambia. Med Vet Entomol 5: 465-476.

18. Georghiou GP, Meltcalf RL, Gidden FE (1966) Carbamate resistance in mosquitoes. Selection of Culex pipiens fatigans Wied for resistance to Baygon. Bull WHO 35: 691-708.

19. Raymond M, Fournier D, Bride JM, Cuany A, Bergé JB, et al. (1986) Identification of resistance mechanisms in Culex pipiens (Diptera: Culicidae) from southern France: Insensitive acetylcholinesterase and detoxifying oxidases. J Econ Entomol 79: 1452.

20. Pasteur N, Iseki A, Georghiou GP (1981) Genetic and biochemical studies of the highly active esterases A'and B associated with organophosphate resistance in mosquitoes of the Culex pipiens complex. Biochemical Genetics 19: 909-919.

21. Pasteur N, Pasteur G, Bonhomme F, Britton-Davidian J (1988) Practical isozyme genetics. Ellis Horwood, Chichester, UK.

22. Finney DJ (1971) Probit analysis. Cambridge University Press, Cambridge, UK.

23. Ben Cheikh H, Ben Ali-Houas Z, Marquine M, Pasteur N (1998) Resistance to organophosphorus and pyrethroid insecticides in Culex pipiens (Diptera: Culicidae) from Tunisia (North Africa). J Med Entomol 35: 251-260.
24. Liu H, Xu Q, Zhang L, Liu N (2005) Chlorpyrifos resistance in mosquito Culex quinquefasciatus. J Med Entomol 42: 815-820.

25. Whyard S, Downe AFR, Walker VK (1994) Isolation of an esterase conferring insecticide resistance in the mosquito Culex tarsalis. Insect Biochem Mol Biol 24: 819-827.

26. Tomita T, Kono Y, Shimada T (1996) Chromosomal localization of amplified esterase genes in insecticide resistant Culex mosquitoes. Insect Biochem Mol Biol 26: 853-857.

27. Hemingway J, Karunaratne SH (1998) Mosquito carboxylesterases: A review of the molecular biology and biochemistry of a major insecticide resistance in mechanism. Med Vet Entomol 12: 1-12.

28. Hemingway J, Hawkes N, Prapanthadara L, Jayawardenal KG, Ranson $H$ (1998) The role of gene splicing, gene amplification and regulation in mosquito insecticide resistance. Phil trans R Soc Lond B Biol Sci 353: 1695-1699.

29. Bisset JA, Rodriguez MM, Diaz C, Soca A (1999) Characterization of resistance to organophosphate insecticides, carbamates, and pyrethroids in Culex quinquefasciatus from the state of Miranda, Venezuela. Rev Cubana Med Trop 51: 89-94.

30. Rodriguez MM, Bisset J, Fernandez DMD, Lauzan L, Soca A (2001) Detection of insecticide resistance in Aedes aegypti (Diptera: Culicidae) from Cuba and Venezuela. J Med Entomol 38: 623-628.

31. Macoris MLG, Andrighetti MTM, Takaku L, Glasser CM, Garbeloto VC, et al. (2003) Mem. Inst. Oswaldo Cruz, Rio de Janeiro 98: 703-708. 